\title{
Moderate pathogenic effect of Ligophorus uruguayense (Monogenoidea, Ancyrocephalidae) in juvenile mullet Mugil liza (Actinopterygii, Mugilidae) from Brazil
}

\author{
EDUARDO PAHOR-FILHO ${ }^{1}$, MARTA C. KLOSTERHOFF ${ }^{2}$, NATALIA \\ C. MARCHIORI ${ }^{3}$ and JOABER PEREIRA JÚNIOR ${ }^{4}$ \\ ${ }^{1}$ Centro de Aquicultura da Universidade Estadual Paulista/UNESP - CAUNESP, Via de \\ Acesso Prof. Paulo Donato Castellane, s/n, 14884-900 Jaboticabal, SP, Brazil \\ ${ }^{2}$ Laboratório de Imunologia e Patologia de Organismos Aquáticos, Universidade Federal \\ do Rio Grande, Rua do Hotel, 2, 96210-030 Rio Grande, RS, Brazil \\ ${ }^{3}$ Empresa de Pesquisa Agropecuária e Extensão Rural de Santa Catarina - Epagri, Campo Experimental \\ de Piscicultura, Av. José Francisco Bernardes, 258, 88340-000 Camboriú, SC, Brazil \\ ${ }^{4}$ Laboratório de Parasitologia de Organismos Aquáticos, Universidade Federal do Rio \\ Grande/FURG, Rua do Hotel, 2, 96210-030 Rio Grande, RS, Brazil \\ Manuscript received on March 27, 2017; accepted for publication on May 24, 2017
}

\begin{abstract}
Monogenoidea pathogenic activity can elicit various histological responses in fish. Species of Ligophorus are specific parasites of mullets, and its relationship with host fish may result in a moderate pathogenic action. In order to ascertain this relationship, estuarine mullets (Mugil liza) were collected in an estuary, reared in laboratory, for three weeks, and forwarded for histological and parasitological analyses. Ligophorus uruguayense (Monogenoidea) infestation in the gills of the mullets was identified. The severe infestation by only one species of Monogenoidea may result from the specificity of these parasites to mullets. Mullets submitted to histological analysis exhibited respiratory epithelium detachment; mild, moderate and severe hyperplasia of the respiratory epithelium; atrophy; and telangiectasia of the gills. This is the first study reporting that mullets highly infested by Monogenoidea can show mild $(100 \%)$ to severe (20\%) gill changes with a distinct frequency of occurrence. Because of the high prevalence of mild alterations observed, it is possible to accept that L. uruguayense is moderately pathogenic to M. liza, even during high prevalence and intensity of infestation, as a result of its specificity.
\end{abstract}

Key words: aquaculture, histological changes, Monogenoidea, Mugilidae, parasitosis.

\section{INTRODUCTION}

Species of Ligophorus Euzet and Suriano, 1977 (Ancyrocephalidae, Monogenoidea) parasitize marine fish and are highly specific for mullet species. The Ligophorus/Mugilidae specificity

Correspondence to: Eduardo Pahor-Filho

E-mail: efpahor@gmail.com suggests that this is an association that results from a long coevolutionary process (Euzet and Suriano 1977, Marchiori et al. 2015). In addition, studies have shown that long coevolutionary relationships can influence pathogenicity of the parasite, which certainly reflects selection processes of the host populations (Poulin et al. 2000). Other authors showed this phenomena, even in high prevalence 
and intensity of infestation by Ligophorus spp. of wild mullet, apparently without causing severe damage to the host (Merella and Garippa 2001).

Parasites belonging to this genus are oviparous and monoxenous and, therefore, may proliferate rapidly under intensive farming systems. Six species of Ligophorus are so far known on the Atlantic coast of South America, all parasites of the same host species Mugil liza Valenciennes 1836: L. uruguayense Failla-Siquier and Ostrowski de Núñez 2009 from Laguna de Rocha, Uruguay (was described in Mugil platanus, posteriorly synonymized with M. liza); L. saladensis Marcotegui and Martorelli 2009 from Samborombón Bay, Argentina; and four other species from the Guandu River, State of Rio de Janeiro, Brazil, namely L. brasiliensis, L. guanduensis, L. lizae and $L$. tainhae, all described by Abdallah et al. (2009). In addition, $L$. uruguayense was reported recently for the first time on the Brazilian coast by Pahor-Filho et al. (2012).

It is not easy to differentiate among closely related spp. of Ligophorus due to the small size of the main diagnostic structures associated with the genus and their close resemblance under an optical microscope (Sarabeev et al. 2005). Nevertheless, Marchiori et al. (2015) have confirmed the validity of two closely related species, L. uruguayense and L. saladensis, through a combined morphological and molecular approach.

Studies have shown the potential damage caused by Monogenoidea species to their hosts (Kristmundsson et al. 2006, Hutson et al. 2007, Jørgensen et al. 2009). These parasites frequently decrease body weight (Ranzani-Paiva and SilvaSouza 2004), or even cause death of the host (Montero et al. 2004, Mansell et al. 2005, Dezfuli et al. 2007). In the gills, Monogenoidea can cause diverse responses that depend on the pathogenicity of the parasite species, such as: mucus release, leucocytes infiltration (Arafa et al. 2009), telangiectasia, necrosis (Schalch et al. 2006), lamellar fusion (Campos et al. 2011), and reduction in the number of chloride cells (Dezfuli et al. 2007). Therefore, the understanding of the relationship among mullets and their parasites contributes to the development of new prophylactic management strategies in farming systems.

This study aims to analyse the parasitological indexes and the frequency of histological changes caused by infestation of the estuarine mullets by L. uruguayense, Monogenoidea. We report that estuarine mullets highly infested by Monogenoidea exhibited mild to severe gill changes, with a distinct frequency of occurrence. These advances can contribute positively to the development of prophylactic techniques in the management of mullet rearing systems.

\section{MATERIALS AND METHODS}

\section{FISH AND ACCLIMATION IN LABORATORY}

Sixty juvenile mullets $(1.2 \pm 0.29 \mathrm{~g}, 4.5 \pm 0.5 \mathrm{~cm})$ were captured from a stream that flows into the Cassino beach, Rio Grande-RS, Brazil ( $32^{\circ} 11$ ' 55" $\left.\mathrm{S}, 52^{\circ} 11^{\prime} 14^{\prime \prime} \mathrm{W}\right)$ with the aid of a trawl net ( $3 \mathrm{~m}$ x $1.5 \mathrm{~m}$ x $5 \mathrm{~mm}$ ), during winter (July, 2015). The fish were transported alive to the laboratory and acclimated for 3 weeks in a 1000-L fiber tank to simulate a farming condition of mullets. A $20 \%$ daily renewal rate of tank volume was performed and maintained the same original estuarine conditions: salinity $\left(10 \mathrm{mg} \mathrm{L}^{-1}\right)$, constant aeration, photoperiod (12 h light), $\mathrm{pH}$ (7.5), dissolved oxygen (6.22 mg $\left.\mathrm{L}^{-1}\right)$, temperature $\left(22{ }^{\circ} \mathrm{C}\right)$ and total ammonia $(0.26$ $\mathrm{mg} \mathrm{L}^{-1}$ ).

Recognition of mullet $M$. liza has been done through the visualization of morphological characteristics, as an elongated body (fins formula) - Dorsal 1: IV; Dorsal 2: I + 8; Anal: III + 8, and approximately 36 transverse series of scales on sides of the body. Besides, mullet is a coastal fish and inhabits estuarine regions during the winter to complete development of its juvenile phase. 
The parameter measurements were performed using an oximeter and a $\mathrm{pH}$ meter (YSI 55/12 FT, USA). Water samples from the rearing tank were sent to the laboratory, and total ammonia was measured through Nessler's reagent, which detects the presence of ammoniacal nitrogen. During the acclimation period, a commercial diet INVE® with $28 \%$ crude protein was used to feed the fish, and the water quality parameters remained in an acceptable range for fish (Vinatea-Arana 2003). There was $100 \%$ survival of fish during the three weeks rearing period in laboratory.

\section{PARASITOLOGICAL ANALYSIS}

The necropsies were performed using 40 fish (whole gill arches), in which the minimum sample size was chosen according to Marques and Cabral (2007), to give reliability to the parasitological analysis. The hosts were euthanised using a section of the medullae to the head, as this does not compromise the estimation of parasitological indexes (Eiras et al. 2006). The collection, fixation and preparation of parasites for identification were performed according to Eiras et al. (2006). Monogenoidea were preserved in 5\% formaldehyde and transferred to $70 \%$ ethanol after $24 \mathrm{~h}$. Some specimens were stained with Masson trichrome or Semichon's carmine, dehydrated in $70-100 \%$ ethanol, clarified in Faia creosote and mounted in Canada balsam. Other specimens were mounted in Grey-Wess's medium to check the sclerotized pieces and copulatory apparatuses, both male and female. Parasitological indexes were determined using the calculation of the prevalence, intensity of infestation, mean intensity of infestation and mean abundance, according to Bush et al. (1997), and were calculated using the appropriate parasitological statistical analysis protocol Quantitative Parasitology (Reiczigel and Rózsa 2005).

\section{HISTOLOGICAL ANALYSIS OF THE GILLS}

For histological analysis, 20 fish were euthanized with benzocaine $\left(100 \mathrm{mg} \mathrm{L}^{-1}\right)$. Gill tissue samples were fixed in Bouin solution during $4 \mathrm{~h}$, and after this period, they were maintained in $70 \%$ ethyl alcohol to be processed histologically. The samples were embedded in Paraplast (SigmaBrazil). Histological sections of $5 \mathrm{~mm}$ were stained with hematoxylin and eosin. The histopathologies were classified according to Randi et al. (1996) and Pahor-Filho et al. (2014), in which a red line in the photomicrograph shows the limit of the affected portion in gill filaments. Thus, it was considered 'mild' when hyperplasia affected less than half of the gill filament length, 'moderate' when it affected more than half of the gill filament length, and 'severe' when it affected the entire gill filament length. Photomicrographs were taken with a Leica DM2500 microscope. The occurrence of histological changes was quantified in the 20 gills forwarded to histological analysis, on a scale between 0 to $100 \%$.

\section{ETHICAL STATEMENT}

The experimental procedures were approved by the Ethics Committee Approval - 002234/15/ CEUA/UNESP) and conducted according to the guidelines of ethical principles in animal experimentation, adapted by the Colégio Brasileiro de Experimentação Animal (COBEA).

\section{RESULTS}

L. uruguayense Failla-Siquier and Ostrowski de Núñez 2009 (Ancyrocephalidae, Monogenoidea) were identified in mullet's gills. Parasitological indexes of 40 fish were: prevalence (100\%), intensity of infestation (2-125), mean intensity of infestation $(25.2 \pm 5.1)$, and mean abundance (25.2 \pm 5.1$)$. 
The following histological changes have been observed: respiratory epithelium detachment; mild, moderate and severe hyperplasia of the respiratory epithelium; atrophy; and telangiectasia were described (Figure 1). Out of 20 fish analysed, all exhibited mild hyperplasia; 8 exhibited telangiectasia; 6 exhibited moderate hyperplasia and respiratory epithelium detachment; and 4 exhibited severe hyperplasia and necrosis of the respiratory epithelium.

\section{DISCUSSION}

A high prevalence of Ligophorus spp. infestation in Mugil species has been reported by other researchers (Sarabeev and Balbuena 2004, Sarabeev et al. 2005, Failla-Siquier and Ostrowski de Núñez 2009). The high prevalence (100\%) and intensity of infestation (2-125) by only one species of Ligophorus (Monogenoidea) found in M. liza from this study, may result from the specificity of these parasites to mullets (Euzet and Suriano 1977, Marchiori et al. 2015), and by the life cycle of fish, since it forms shoals and stay in estuaries during development of their juvenile phase (Godinho 2004). These sites contain high concentrations of organic matter and high densities of fish of the same species, which increase the possibility of parasites transmission (Buchmann and Lindenstrøm 2002). Normally, infestation by only one parasitic species occurs in very small mullets, such as those used in the current study. With the growth and development of fish, there is infestation by other parasites.

Monogenoidea spp. can cause several injuries in fish, from mild hyperplasia to death, depending on its pathogenicity and the type of attachment organs to the host (Buchmann and Lindenstrøm 2002). Mild effects, such as hyperplasia, caused by Monogenoidea were observed in kingfish (Seriola lalandi) heavily infested by Zeuxapta seriolae (Mansell et al. 2005), as well as tilapia (Oreochromis niloticus) infested by Cichlidogyrus sclerosus, according to Azevedo et al. (2006). Corroborating these cited studies, we found a moderate pathogenicity as result of $L$. uruguayense parasitosis in the mullets, even with high incidence of mild hyperplasia (100\%), observed in infested gills. However, these parasites attach to the gills by the haptor and feed on skin cells and blood (Buchmann and Lindenstrøm 2002), and may until to cause suppression of the host immune system (Chaves et al. 2006). Thus, it is possible to suggest that alterations caused in the gills of juvenile mullets may be due to moderate pathogenicity of L. uruguayense. According to Buchmann and Lindenstrøm (2002), some mechanisms are responsible for the success of this relationship, such as the presence of parasite receptors that recognise the adequate host, the infestation site, and the host's innate immune system that preserves the specific parasite.

On the other hand, infestation by $L$. uruguayense, in our study, can be associated to severe damage observed in gills of juvenile mullets. However, a low incidence of severe hyperplasia and necrosis of the respiratory epithelium were observed in $20 \%$ of the hosts. Moreover, these data confirm the hypothesis of Thatcher (1991), which supports that parasites can cause severe injuries to the host, and only in some cases this is detected in nature, because these debilitated fish are preyed upon quickly. Other authors also reported severe changes caused by Monogenoidea in other fish, such as fusion of the secondary lamellae (Kristmundsson et al. 2006), atrophy of the respiratory epithelium, haemorrhage (Dezfuli et al. 2007), and epithelial necrosis (Arafa et al. 2009), suggesting that $L$. uruguayense also might cause or induce severe damage in debilitated juvenile mullets, captured by trawl net in the estuary.

In Brazil, M. liza has high demand for fishermen and local consumers (Godinho 2004). Pilot tests for breading of this fish have been successfully carried out in State of Santa Catarina, evidencing 

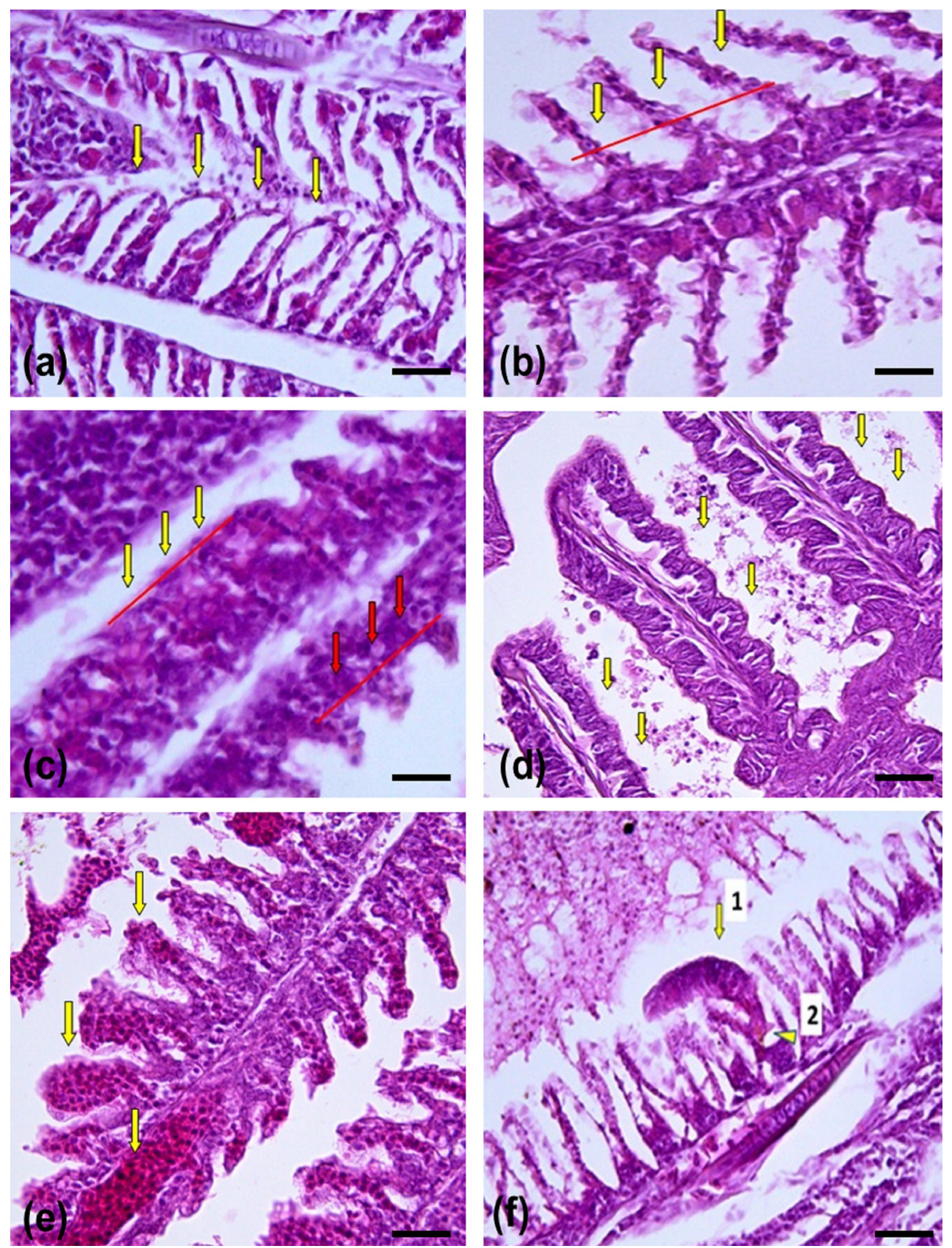

Figure 1 - Longitudinal section of gills of juvenile mullet Mugil liza with histological alterations caused by infestation of Ligophorus uruguayense. (a) respiratory epithelium detachment (yellow arrow). (b) mild hyperplasia (yellow arrow). Red line shows that hyperplasia affects less than half of the gill filament length. (c) moderate hyperplasia (red arrow). Red line shows hyperplasia affects half the length of the filament. Severe hyperplasia (yellow arrow). Red line shows that hyperplasia affects all the gill filament length. (d) necrosis of the respiratory epithelium (yellow arrow). (e) telangectasia (yellow arrow). (f.1) Ligophorus uruguayensis fixed on the gill filament (yellow arrow). (f.2) Haptor (yellow arrow). ( $\mathrm{n}=$ twenty fish). All hematoxylin eosin staining, Scale bar $=200 \mu \mathrm{m}$. 
their productive potential to Brazilian aquaculture (Carvalho et al. 2015). In our study, even the rearing system containing acceptable water quality parameters for marine fish, the mullets infested by L. uruguayense exhibited telangectasia (8 fish), moderate hyperplasia and respiratory epithelium detachment (6 fish), and severe hyperplasia and necrosis (4 fish). These results may be aggravated in cases of water quality fall, in which fish become more susceptible to parasitic infestations in fish farms.

Monogenoidea proliferate rapidly in breeding systems, and attacks the host by the haptor's abrasive activity. Therefore, the maintenance of water quality and the prophylaxis of the medium are fundamental factors to avoid the damage to the fish (Kristmundsson et al. 2006, Hutson et al. 2007, Jørgensen et al. 2009). A better understanding of the host-parasite relationship as well as the parasite species, parasitological indexes and host histological damage may contribute to the improvement of prophylactic techniques in the management of mullets in rearing systems. The preventive techniques for parasite control aim to interrupt or prevent the development of the parasite life cycle. Thus, it is possible to reduce the intensity of parasitic infestation, increasing the possibility of success in breeding systems.

Here, we determined the method of parasitism in juvenile mullets, and the damage observed in the gills of the host. However, by the high prevalence of mild alterations observed in the gills of mullets, it is possible to accept that L. uruguayense is moderately pathogenic to $M$. liza, even during high prevalence and intensity of infestation, as a result of its specificity. Further studies should investigate whether high infestation of L. uruguayense can cause mortality in other life stages, such as adults and breeding mullets, and whether the presence of these parasites may increase histological changes in the host.

\section{REFERENCES}

ABDALLAH VD, AZEVEDO R AND LUQUE JL. 2009. Four new species of Ligophorus (Monogenea: Dactylogyridae) parasitic on Mugil liza (Actinopterygii: Mugilidae) from Guandu River, Southeastern. Braz J Vet Parasitol 95: 855864.

ARAFA SZ, EL-NAGGAR MM AND EL-ABBASSY SA. 2009. Mode of attachment and histopathological effects of Macrogyrodactylus clarii, a monogenean gill parasite of the catfish Clarias gariepinus, with a report on host response. Acta Parasitol 54: 103-112.

AZEVEDO TMP, MARTINS ML, BOZZO FR AND MORAES FR. 2006. Haematological and gill responses in parasitized tilapia from valley of Tijucas River, SC, Brazil. Sci Agric 63: 115-120.

BUCHMANN K AND LINDENSTRØM T. 2002. Interactions between monogenean parasites and their fish hosts. Int $\mathrm{J}$ Parasitol 32: 309-319.

BUSH AO, LAFFERTY KD, LOTZ JM AND SHOSTAK AW. 1997. Parasitology meets ecology on terms: Margolis et al. Revisited. J Parasitol 83: 575-583.

CAMPOS CM, MORAES JRE AND MORAES FR. 2011. Histopathology of gills of Piaractus mesopotamicus (Holmberg, 1887) and Prochilodus lineatus (Valenciennes, 1836) infested by monogenean and myxosporea, caugth in Aquidauana River, State of Mato Grosso do Sul, Brazil. Rev Bras Parasitol Vet 20: 67-70.

CARVALHO CVA, STERZELECKI FC, BALOI MF, SILVA VN, MICHELOTTI B, MAGNOTTI C, PEDROTTI FS AND CERQUEIRA VR. 2015. Reprodução e larvicultura da tainha M. liza no Estado de Santa Catarina. 2015. In: Fenacam 2015 \& Laqua 2015. International Conference \& Exposition. Fortaleza-CE.

CHAVES IS, LUVIZOTTO-SANTOS R, SAMPAIO LAN, BIANCHINI A AND MARTÍNEZ PE. 2006. Immune adaptive response induced by Bicotylophora trachinoti (Monogenea: Diclidophoridae) infestation in pompano Trachinotus marginatus (Perciformes: Carangidae). Fish Shellfish Immunol 21: 242-250.

DEZFULI BS, GIARI L, SIMONI E, MENEGATTI R, SHINN AP AND MANERA M. 2007. Gill histopathology of cultured European sea bass, Dicentrarchus labrax (L.), infected with Diplectanum aequans (Wagener 1857) Diesing 1958 (Diplectanidae: Monogenea). Parasitol Res 100: 707-713.

EIRAS JC, TAKEMOTO RM AND PAVANELLI GC. 2006. Métodos de estudos e técnicas laboratoriais em parasitologia de peixes, $2^{\mathrm{a}}$ ed., Maringá, $199 \mathrm{p}$.

EUZET L AND SURIANO DM. 1977. Ligophorus n. g. (Monogenea, Ancyrocephalidae) parasite des Mugilidae (Teleóstéens) en Méditerranée. Bull Mus Nat His Nat 472: 799-821. 
FAILLA-SIQUIER G AND OSTROWSKI DE NÚÑEZ M. 2009. Ligophorus uruguayense sp. nov. (Monogenea, Ancyrocephalidae), a gill parasite from Mugil platanus (Mugiliformes, Mugilidae) in Uruguay. Acta Parasitol 54: 95-102.

GODINHO HM. 2004. Tainha. In: Baldisseroto BE and Gomes LC (Eds), Espécies nativas para piscicultura no Brasil. RS, Brasil. UFSM, Santa Maria, p. 433-441.

HUTSON KS, ERNST I AND WHITTINGTON ID. 2007. Risk assessment for metazoan parasites of yellowtail kingfish Seriola lalandi (Perciformes: Carangidae) in the South Australian sea-cage aquaculture. Aquaculture 271: 85-99.

JØRGENSEN TR, LARSEN TB AND BUCHMANN K. 2009. Parasite infections in recirculated rainbow trout (Oncorhynchus mykiss) farms. Aquaculture 289: 91-94.

KRISTMUNDSSON AS, BAMBIR H AND HELGASON S. 2006. Gyrodactylus anarhichatis Mo \& Lile (Monogenea: Gyrodactylidae) infection of farmed spotted wolffish, Anarhichas minor Olafsen, in Iceland. J Fish Dis 29: 365370.

MANSELL B, POWELL MD, ERNST I AND NOWAK BF. 2005. Effects of the gill monogenean Zeuxapta seriolae (Meserve, 1938) and treatment with hydrogen peroxide on pathophysiology of kingfish, Seriola lalandi Valenciennes, 1833. J Fish Dis 28: 253-262.

MARCHIORI NC, PARISELLE A, PEREIRA JR J, AGNÈSE JF, DURAND JD AND VANHOVE MP. 2015. A comparative study of Ligophorus uruguayense and Ligophorus saladensis (Monogenea, Ancyrocephalidae) from Mugil liza (Teleostei, Mugilidae) in southern Brazil. Folia Parasitol 62: 1-10.

MARQUES JF AND CABRAL HN. 2007. Effects of sample size on fish parasite prevalence, mean abundance and mean intensity estimates. J Appl Ichthyol 23: 158-162.

MERELLA P AND GARIPPA G. 2001. Metazoan parasites of grey mullets (Teleostea: Mugilidae) from the Mistras Lagoon (Sardinia, western Mediterranean). Sci Mar 65: 201-206.

MONTERO FE, CRESPO S, PADRÓS F, GÁNDARA F, GARCÍA A AND RAGA JA. 2004. Effects of the gill parasite Zeuxapta seriolae (Monogenea: Heteraxinidae) on the amberjack Seriola dumerili Risso (Teleostei: Carangidae). Aquaculture 232: 153-163.

PAHOR-FILHO E, MIRANDA-FILHO KC, KLOSTERHOFF MC, ROMANO LA AND PEREIRA JR J. 2014.
Histopathological and behaviour effects of formaldehyde treatment in juvenile mullet, Mugil liza (Valenciennes). Aquaculture Res 45: 1-6.

PAHOR-FILHO E, MIRANDA-FILHO KC AND PEREIRA JR J. 2012. Parasitology of juvenile mullet (Mugil liza) and effect of formaldehyde on parasites and host. Aquaculture 354: 111-116.

POULIN R, MARSHALL LJ AND SPENCER HG. 2000. Metazoan parasite species richness and genetic variation among freshwater fish species: cause or consequence? Int J Parasitol 30: 697-703.

RANDI AS, MONSERRAT JM AND RODRIGUEZ EM. 1996. Histopathological effects of cadmium on the gills of the freshwater fish, Macropsobrycon uruguayanae Eigenmann (Pisces, Atherinidae). J Fish Dis 19: 311-322.

RANZANI-PAIVA MJT AND SILVA-SOUZA AT. 2004. Co-infestation of gills by different parasite groups in the mullet, Mugil platanus Gunther, 1880 (Osteichthyes, Mugilidae): Effects on relative condition factor. Braz $\mathrm{J}$ Biol 64: 677-683.

REICZIGEL J AND RÓZSA L. 2005. Quantitative Parasitology 3.0. Budapest. http://www.bahav.org/qp/ qp.htm.

SARABEEV VL AND BALBUENA JA. 2004. Ligophorus pilengas $\mathrm{n}$. sp. (Monogenea: Ancyrocephalidae) from the introduced so-iuy mullet, Mugil soiuy (Teleostei: Mugilidae), in the Sea of Azov and the Black Sea. J Parasitol 90: 222-228.

SARABEEV VL, BALBUENA JA AND EUZET L. 2005. Taxonomic status of Ligophorus mugilinus (Hargis, 1955) (Monogenea: Ancyrocephalidae), with a description of a new species of Ligophorus from Mugil cephalus (Teleostei: Mugilidae) in the mediterranean basin. J Parasitol 9: 14441451.

SCHALCH SHC, MORAES FR AND MORAES JRE. 2006. Efeitos do parasitismo sobre a estrutura branquial de Leporinus macrocephalus Garavello e Britsk, 1988 (Anastomidae) e Piaractus mesopotamicus Holmberg, 1887 (Osteichthyes: Characidae). Rev Bras Parasitol Vet 15: 110-115.

THATCHER VE. 1991. Patologia de peixes da Amazônia Brasileira, 1. Aspectos Gerais. Acta Amazon 11: 125-140.

VINATEA-ARANA L. 2003. Princípios químicos de qualidade da água em aquicultura: uma revisão para peixes e camarões, $2^{\mathrm{a}}$ ed., Florianópolis: Ed. da UFSC. 